\title{
Environmental and occupational respiratory diseases - 1045. Skin prick tests and allergen- specific lgE tests for fungus in patients with chronic lower respiratory symptoms
}

\author{
Jae Woo Jung, Jae Chol Choi, Jong Wook Shin, Jae Yeol Kim, In Won Park, Byoung Whui Choi*
}

From 2nd WAO International Scientific Conference (WISC 2012)

Hyderabad, India. 6-9 December 2012

\section{Background}

Skin prick tests (SPTs) has relatively a good correlation with allergen-specific IgE against house dust mites (HDM) and pollens, whereas their correlation to fungi remains low. We aimed to investigate the correlation between results of serum specific IgE and SPTs for HDM or fungi in patients with chronic lower respiratory symptoms. The clinical difference between serum fungus or HDM-specific IgE-positive and -negative groups was also examined.

\section{Methods}

A total of 89 patients underwent both SPT and serum specific IgE test to D. farinae, D. pteronyssiuns and 5 fungi (Penicillium notatum, Cladosporium, Aspergillus fumigatus, and Alternaria,Fusarium spp.) with chronic lower respiratory symptoms were included in this study.

\section{Results}

SPT and serum specific IgE tests for HDM were positive in $20.2 \%$ and $38.2 \%$ and for fungi $5.6 \%$ and $41.6 \%$. The $\mathrm{k}$ statistic for the agreement between SPT and serum specific IgE test about HDM was relatively high (0.425, $\mathrm{p}<0.001)$ compared with fungi $(\mathrm{k}=0.102, \mathrm{P}=\mathrm{NS})$. In patients with negative SPT to HDM, total IgE (741.15 vs. $84.33 \mathrm{KU} / \mathrm{L})$ was higher and FEV1 \% predicted $(76.95 \%$ vs. $90.33 \%)$ and PC20 (2.57 vs. $1.32 \mathrm{mg} / \mathrm{ml})$ were lower in the serum HDM-specific IgE positive group than in negative group $(\mathrm{P}<0.05)$. In patients with negative SPT to fungi, total IgE ( 480.32 vs. $119.67 \mathrm{KU} / \mathrm{L})$ was higher in the serum

Internal Medicine, Chung-Ang University Hospital, Seoul, South Korea fungi-specific IgE positive group than in negative group $(\mathrm{P}<0.05)$.

\section{Conclusions}

The rate of successful detection of HDM and fungi using SPT was low compared to serum specific IgE. Thus, serum specific IgE might need to detect HDM and fungus allergies in patients with chronic lower respiratory symptoms.

Published: 23 April 2013

doi:10.1186/1939-4551-6-S1-P44

Cite this article as: Jung et al: Environmental and occupational respiratory diseases - 1045. Skin prick tests and allergen-specific IgE tests for fungus in patients with chronic lower respiratory symptoms. World Allergy Organization Journal 2013 6(Suppl 1):P44.

Submit your next manuscript to BioMed Central and take full advantage of:

- Convenient online submission

- Thorough peer review

- No space constraints or color figure charges

- Immediate publication on acceptance

- Inclusion in PubMed, CAS, Scopus and Google Scholar

- Research which is freely available for redistribution 